\title{
原子発光検出器付ガスクロマトグラフを用いる 化学兵器用剂ならびに関連化合物の分析
}

\author{
金森美江子 ${ }^{\circledR 1}$, 立川 真澄 ${ }^{1,2}$, 關岡 亮二 ${ }^{1,3}$, 関 口 浩 ${ }^{1,3}$, \\ 丸子 恒 ${ }^{1,3}$, 佐藤 貴史 $^{1,3}$, 瀬戸 康雄 ${ }^{1}$
}

\section{1 緒言}

1994 年から 1995 年にかけて発生したオウム真理教団に よる松本及び東京地下鉄サリン事件 ${ }^{1 / 2)}$ や, アメリカ合衆国 での郵便物䈐瘟菌事件 ${ }^{3)}$ な゙, 化学・生物兵器を用いた無 差別テロが発生し人々を震撼させたが, 今後もその可能性 は否定できない.

化学兵器用剤の分析法としては, 著者らが既に総説など で説明しているように ${ }^{4) 5)}$, 化学兵器禁止条約に係る化学査 察における分析が中心であるが，ガスクロマトグラフィー/ 質量分析 (GC/MS) 法が基本となっている ${ }^{6)}$. GC/MS 法 は, 科学捜査の観点からも薬毒物検査の基本分析であり 加えて化学剤, 分解物, 関連化合物の検查法として活用さ れている ${ }^{8)}$. 試料によっては抽出などの前処理が必要とな るが，化学剂の揮発性・易分解性という特徵をかんがみれ ば，前処理が困難である複雑なマトリクスを有する試料に よっては，目的化合物の検出が妨害されるなどの影響が認 められることがある. GC を用いた化学兵器用剤の分析手 法として, 電気化学検出器 $(\mathrm{ECD})^{9)}$ や窒素リン検出器 $(\mathrm{NPD})^{10)}$, パルスド炎光光度検出器 (pulsed FPD $)^{11}$ などを 用いた元素特異的検出が報告されているが, これらの検出 器は高感度である反面, 特定の元素しか検出することがで きない.

原子発光検出器 (AED) は, プラズマにより化合物を原 子に分解し, 励起された原子が基底状態に戻る時に元素特 有の光を発生させ測定するもので, 様々な元素を選択的か つ高感度で検出できる手法であり ${ }^{12)}$, 石油化学の分野をは じめ, ヘテロ元素を有する化合物群の一斉分析法として活 用され ${ }^{13)}$ ，化学兵器用剤においてもマスタードガス (HD) や匕素化合物のへテロ元素の検出に応用されている ${ }^{14) \sim 17)}$. 化学兵器禁止法により特定物質に指定されている化学兵器 用剤の大半は, リンやフッ素, 塩素, 硫黄, 七素, 窒素な

\footnotetext{
${ }^{\circledR}$ E-mail : kataoka@nrips.go.jp

1 科学警察研究所 : 277-0882 千葉県柏市柏の葉 6-3-1

2 株式会社ハイテック：260-0045 千葉県千葉市中央区弁天 1-15-1 細川ビル 6F

3 警視庁：100-8929 東京都千代田区霞が関 2-1-1
}

どの特徵的な元素を有しており（Fig. 1)，目的化合物の保 持指標と含有元素の有無から, 童雑物含有試料中の化学兵 器用剤の迅速スクリーニングが可能であると考えられる.

本研究に打いては, 化学兵器禁止法で使用などが規制さ れている特定物質のうち当研究所で保有する 11 種と, 偏 吐（くしゃみ）剤 2 種, 護身用スプレー成分である催涙成 分 4 種 (Fig. 1), 化学兵器用剂の製造中間体や副生成物, 分解物などの関連化合物 17 種（Fig. 2) について GC-AED を用いて測定を行い，再現性や定量性について検討を行っ た. さらに, 夾雑物として, 化学兵器禁止機関 (OPCW) においても化学剤分析の検定試験用試料として用いら $れ^{18)}$, 化学剂と同様に揮発性の高いガソリンを選び, ガソ リンを含有する試料からの化学兵器用剤のスクリーニング への応用についても報告する.

$$
2 \text { 実験 }
$$

\section{$2 \cdot 1$ 試薬ならびに試料の調製}

化学兵器用剂である, サリン ( $O$-isopropyl methylphosphonofluoridate, $\mathrm{GB})$, ソマン (O-pinacolyl methylphosphonofluoridate, GD), タブン ( $O$-ethyl $N, N$-dimethyl phosphonocyanidate, GA), シクロヘキシルサリン (O-cyclohexyl methylphosphonofluoridate, GF), VX (O-ethyl $S$-2diisopropylaminoethyl methylphosphonothiolate), RVX ( $O$-isobutyl S-2-diethylaminoethyl methylphosphonothiolate), マスタードガス [bis(2-chloroethyl)sulfide, HD], ル イサイト1（2-chlorovinyldichloroarsine, L1)，窒素マス タード 1 [bis(2-chloroethyl)ethylamine, HN1］，窒素マス タード 2 [bis(2-chloroethyl) methylamine, HN2], 窒素マス タード 3 [tris(2-chloroethyl)amine, HN3], ジフェニルシ アノアルシン (DC)，o-クロロベンジリデンマロノニトリ ル（CS），ならびに関連化合物であるメチルホスホン酸ジ イソプロピル（DIMP）及びメチルホスホン酸ジシクロヘ キシル（DCMP）は，合成した. VX（約 $70 \%$ ）以外の化 学兵器用剤の純度は, $98 \%$ 以上であった。

メチルホスホン酸ジメチル (DMMP), メチルホスホン 酸ジエチル (DEMP), リン酸トリメチル (TMPO), リン 


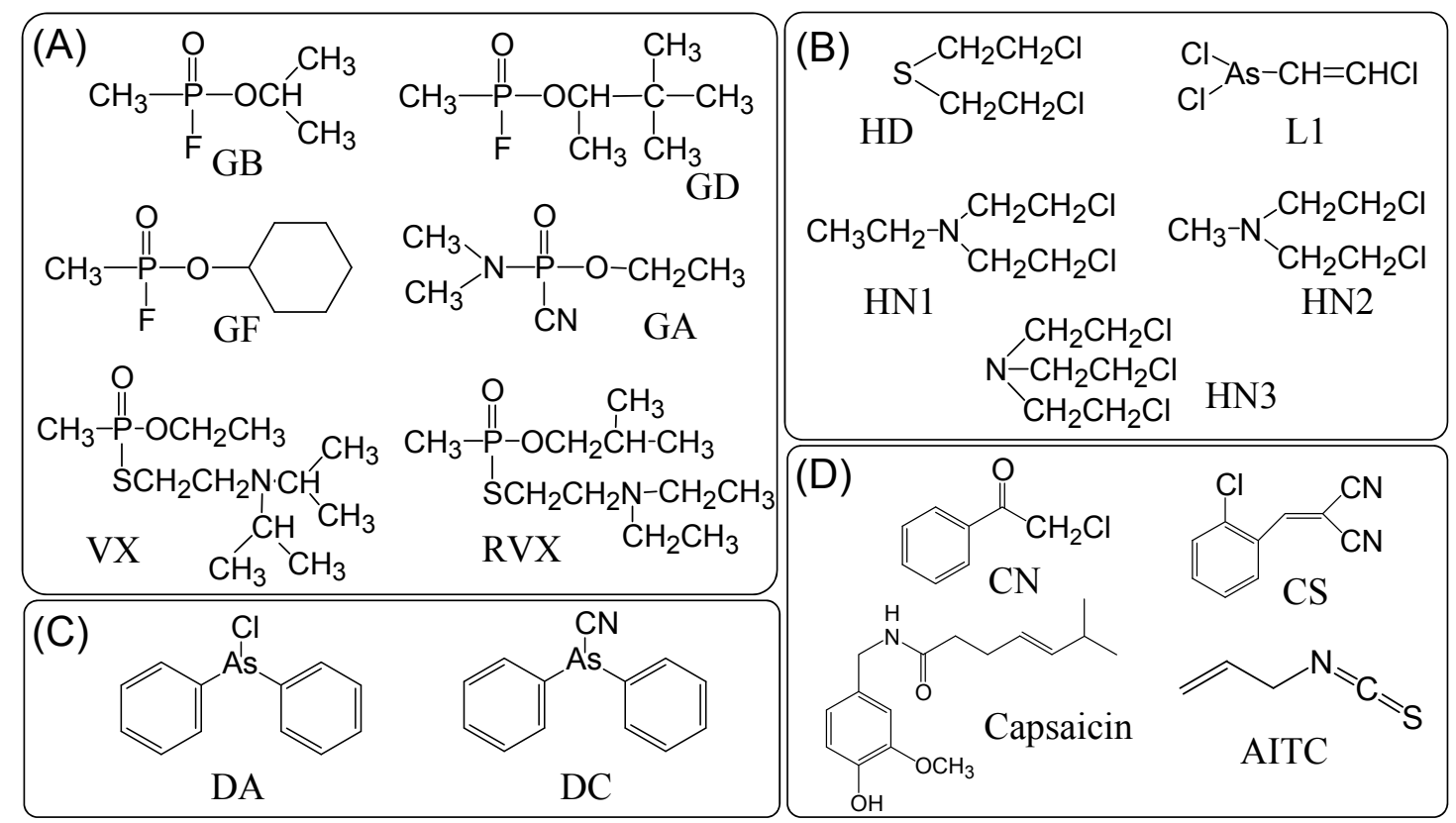

Fig. 1 Chemical structures of nerve gases (A), blistering agents (B), vomiting (sneezing) agents $(\mathrm{C})$ and lachrymators (including active components of tear gas spray, D), subjected to GC-AED
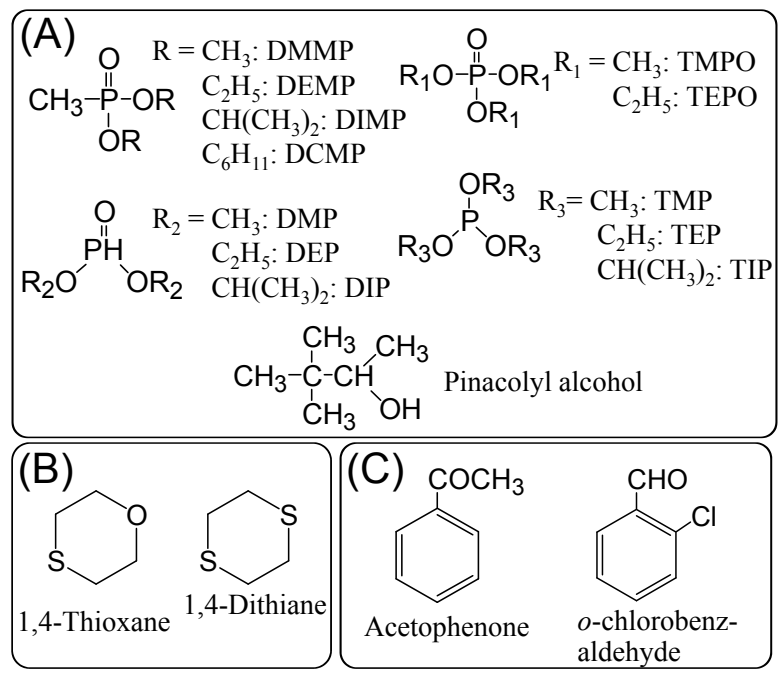

Fig. 2 Chemical structures of related compounds of nerve gases (A), blistering agents (B) and lachrymators (C) subjected to GC-AED

酸トリエチル (TEPO), 亜リン酸ジメチル（DMP），亜リ ン酸ジエチル (DEP), 亜リン酸ジイソプロピル (DIP), 亜 リン酸トリメチル（TMP）, 覀リン酸トリエチル（TEP）, 亜リン酸トリイソプロピル（TIP）は，東京化成工業製の ものを使用した．カプサイシン，1,4-ジチアン，1,4-チオキ サン, ピナコリルアルコールはシグマアルドリッチ製を使 用した，2-クロロアセトフェノン $(\mathrm{CN})$, アセトフェノン, $o$-クロロベンズアルデヒドは, 和光純薬工業製を使用し た. ジフェニルクロロアルシン（DA）は保土谷化学工業製 を使用した。その他の試薬についてはすべて分析用試薬を 使用した。
CN， CS，カプサイシンは各々アセトニトリルに，DA， DC，1,4-ジチアンは各々 $n$-ヘキサンに溶解希釈し， $10 \mathrm{mg}$ $\mathrm{mL}^{-1}$ 溶液を調製した。 その他の化学兵器用剤ならびに関 連化合物（常温で液体）については, 原液をマイクロシリ ンジで取り $n$-ヘキサンで希釈し, $10 \mu \mathrm{L} \mathrm{mL}^{-1}$ 溶液を調製 した。これらを個々あるいは一部混合してジクロロメタン で希釈し， 2, $10 ， 20 ， 50,100,200 \mu \mathrm{g} \mathrm{mL}^{-1}$ (または $\mathrm{nL}$ $\left.\mathrm{mL}^{-1}\right)$ 溶液を調製した。内部標準物質として, アントラセ ンあるいは $n$-ノナデカンを使用して $500 \mu \mathrm{g} \mathrm{mL}^{-1}$ アセトニ トリル溶液を調製し， $50 \mu \mathrm{g} \mathrm{mL} \mathrm{mL}^{-1}$ になるように分析試料に 添加した.

\section{$2 \cdot 2$ 夾雑物含有試料の調製}

ENEOS レギュラーガソリン（JX 日鉱日石エネルギー 製)については, $n$-ヘキサンで 10 倍希釈液を調製した。こ れに，GA 及び GB（ $n$-ヘキサン溶液）を添加・希釈して分 析試料を調製し，二つに分けて，各々 GC/MS ならびに GC-AED 測定へと進めた.

\section{2・3 GC-AED}

以下の条件で GC-AED 測定を実施した.

装置: G2350A 原子発光検出器（Joint Analytical Systems 製）付き 6890 シリーズガスクロマトグラフ (Agilent Technologies 製)，カラム: Agilent 製 HP-5MS (30 m ×0.25 $\mathrm{mm}$ i.d., 膜厚 $0.25 \mu \mathrm{m})$, キャリヤーガス : ヘリウム $(1.5$ $\left.\mathrm{mL} \min ^{-1}\right)$, スプリット比: $20: 1$, カラム温度 : $40{ }^{\circ} \mathrm{C}$ $(1 \mathrm{~min})-\left(20{ }^{\circ} \mathrm{C} \mathrm{min}^{-1}\right)-290{ }^{\circ} \mathrm{C}(5 \mathrm{~min})$, 注入口温度 : $250{ }^{\circ} \mathrm{C}$, 注入量 : $1 \mu \mathrm{L}$, キャビティー及びトランスファー 
Table 1 The chemical warfare agents analyzed and gas chromatography-atomic emission detection results

\begin{tabular}{|c|c|c|c|c|c|c|c|c|c|c|}
\hline & \multirow{2}{*}{\multicolumn{2}{|c|}{ Compound/abbreviation }} & \multirow{3}{*}{$\begin{array}{c}\begin{array}{c}\text { Molecular } \\
\text { formula }\end{array} \\
\mathrm{C}_{4} \mathrm{H}_{10} \mathrm{FO}_{2} \mathrm{P}\end{array}$} & \multirow{3}{*}{$\begin{array}{c}\text { Mol. } \\
\text { Wt. }\end{array}$} & \multirow{3}{*}{$\begin{array}{c}\begin{array}{c}\text { Liquid or } \\
\text { Solid at rt }\end{array} \\
\text { L }\end{array}$} & \multirow{3}{*}{$\begin{array}{c}\begin{array}{c}\text { Density/ } \\
\mathrm{g} \mathrm{mL}^{-1 \text { a) }}\end{array} \\
1.09\end{array}$} & \multirow{3}{*}{$\begin{array}{c}\begin{array}{c}\mathrm{CV} / \\
\%^{\mathrm{b})}\end{array} \\
1.4\end{array}$} & \multicolumn{3}{|c|}{ Retention index } \\
\hline & & & & & & & & Exp. $^{c)}$ & Ref. $1^{\text {d) }}$ & Ref. $2^{\mathrm{e})}$ \\
\hline \multirow[t]{6}{*}{ Nerve gases } & Sarin & GB & & & & & & 811 & 819 & 824 \\
\hline & Soman & GD & $\mathrm{C}_{7} \mathrm{H}_{16} \mathrm{FO}_{2} \mathrm{P}$ & 182 & $\mathrm{~L}$ & 1.02 & 1.2 & $\begin{array}{l}1035 \\
1040\end{array}$ & $\begin{array}{l}1041 \\
1045\end{array}$ & $\begin{array}{l}1045 \\
1049\end{array}$ \\
\hline & Tabun & GA & $\mathrm{C}_{5} \mathrm{H}_{11} \mathrm{~N}_{2} \mathrm{O}_{2} \mathrm{P}$ & 162 & $\mathrm{~L}$ & 1.07 & 1.5 & 1119 & 1128 & 1132 \\
\hline & Cyclohexylsarin & GF & $\mathrm{C}_{7} \mathrm{H}_{14} \mathrm{FO}_{2} \mathrm{P}$ & 180 & $\mathrm{~L}$ & 1.13 & 1.3 & 1205 & & \\
\hline & $\mathrm{vX}$ & & $\mathrm{C}_{11} \mathrm{H}_{26} \mathrm{NO}_{2} \mathrm{PS}$ & 267 & $\mathrm{~L}$ & 1.01 & 3.7 & 1706 & 1714 & 1710 \\
\hline & Russian VX & RVX & $\mathrm{C}_{11} \mathrm{H}_{26} \mathrm{NO}_{2} \mathrm{PS}$ & 267 & $\mathrm{~L}$ & 1.01 & 8.9 & 1725 & & \\
\hline \multirow[t]{5}{*}{ Blistering agents } & Mustard gas & HD & $\mathrm{C}_{4} \mathrm{H}_{8} \mathrm{Cl}_{2} \mathrm{~S}$ & 159 & $\mathrm{~L}$ & 1.27 & 1.7 & 1186 & 1182 & 1173 \\
\hline & Lewisite 1 & L1 & $\mathrm{C}_{2} \mathrm{H}_{2} \mathrm{AsCl}_{3}$ & 208 & $\mathrm{~L}$ & 1.89 & 12.6 & 1082 & 1079 & 1083 \\
\hline & Nitrogen mustard 1 & HN1 & $\mathrm{C}_{6} \mathrm{H}_{13} \mathrm{Cl}_{2} \mathrm{~N}$ & 170 & $\mathrm{~L}$ & 1.09 & 2.3 & 1157 & & \\
\hline & Nitrogen mustard 2 & HN2 & $\mathrm{C}_{5} \mathrm{H}_{11} \mathrm{Cl}_{2} \mathrm{~N}$ & 156 & $\mathrm{~L}$ & 1.15 & 1.4 & 1088 & & \\
\hline & Nitrogen mustard 3 & HN3 & $\mathrm{C}_{6} \mathrm{H}_{12} \mathrm{Cl}_{3} \mathrm{~N}$ & 205 & $\mathrm{~L}$ & 1.24 & 1.0 & 1411 & & \\
\hline \multirow{2}{*}{$\begin{array}{l}\text { Vomiting } \\
\text { (Sneezing) } \\
\text { agents }\end{array}$} & Diphenylchloroarsine & DA & $\mathrm{C}_{12} \mathrm{H}_{10} \mathrm{AsCl}$ & 265 & $\mathrm{~S}$ & - & 2.4 & 1831 & & \\
\hline & Diphenylcyanoarsine & DC & $\mathrm{C}_{13} \mathrm{H}_{10} \mathrm{AsN}$ & 255 & $\mathrm{~S}$ & - & 2.4 & 1879 & & \\
\hline \multirow[t]{4}{*}{ Lachrymators } & 2-Chloroacetophenone & $\mathrm{CN}$ & $\mathrm{C}_{8} \mathrm{H}_{7} \mathrm{ClO}$ & 155 & S & - & 1.3 & 1295 & 1296 & 1283 \\
\hline & $\begin{array}{l}o \text {-Chlorobenzylidene } \\
\text { malononitrile }\end{array}$ & CS & $\mathrm{C}_{10} \mathrm{H}_{5} \mathrm{ClN}_{2}$ & 189 & $\mathrm{~S}$ & - & 1.2 & 1554 & 1569 & 1555 \\
\hline & Capsaicin & & $\mathrm{C}_{18} \mathrm{H}_{27} \mathrm{NO}_{3}$ & 305 & $\mathrm{~S}$ & - & 2.8 & 2571 & 2586 & \\
\hline & Allyl isothiocyanate & AITC & $\mathrm{C}_{4} \mathrm{H}_{5} \mathrm{NS}$ & 99 & $\mathrm{~L}$ & 1.02 & 1.9 & 882 & & \\
\hline
\end{tabular}

a) At 20 or $25{ }^{\circ} \mathrm{C}$. b) Coefficient of variation in within-day $\left(20-38 \mu \mathrm{g} \mathrm{mL}{ }^{-1}\right)$ at carbon $(193 \mathrm{~nm})(n=3)$ c $)$ Retention index for each compound is calculated using its retention time at carbon (193 nm). d) Reference: 21). e) Reference: 22) and 23).

ライン温度 : $290{ }^{\circ} \mathrm{C}$, 検出波長 : $174 \mathrm{~nm}$ (窒素), $178 \mathrm{~nm}$ (リン), $181 \mathrm{~nm}$ (硫黄), $189 \mathrm{~nm}$ (ヒ素), $193 \mathrm{~nm}$ (炭素), $479 \mathrm{~nm}$ (塩素), $690 \mathrm{~nm}$ (フッ素), 使用ガス: 水素 (51.1 $\mathrm{kPa})$, 酸素 $(113.6 \mathrm{kPa}), 10 \%$ メタン $/ 90$ \% 窒素 $(237.3$ $\mathrm{kPa})$.

Moffat $^{19)}$ の式に従い, 指標物質として $n$-アルカンを用 い, 炭素検出波長 $(193 \mathrm{~nm})$ における元素クロマトグラム より, 化学兵器用剤及び関連化合物の保持指標を求めた。 各化合物の検出限界は, 各元素の検出波長における元素ク ロマトグラムでのシグナル/ノイズ $(\mathrm{S} / \mathrm{N})$ 比が 3 であると きの濃度として定義した。

\section{$2 \cdot 4 \mathrm{GC} / \mathrm{MS}$}

以下の条件で GC/MS 測定を実施した.

装置 : Agilent 製 6890 シリーズガスクロマトグラフ及び $5975 \mathrm{~N}$ 質量分析装置, カラム : Agilent 製 HP-5MS (30 m × $0.25 \mathrm{~mm}$ i.d., 膜厚 $0.25 \mu \mathrm{m})$, キャリヤーガス:ヘリウム $\left(1 \mathrm{~mL} \mathrm{~min}^{-1}\right)$, スプリット比: $20: 1$, カラム温度 : $40{ }^{\circ} \mathrm{C}$ $(1 \mathrm{~min})-\left(20{ }^{\circ} \mathrm{C} \mathrm{min}^{-1}\right)-290{ }^{\circ} \mathrm{C}(5 \mathrm{~min})$, 注入口温度 : $250{ }^{\circ} \mathrm{C}$, トランスファーライン温度 : $280{ }^{\circ} \mathrm{C}$, イオン化法 : 電子イオン化 $(\mathrm{EI})$ 法, イオン化電圧 : $70 \mathrm{eV}(34.6 \mu \mathrm{A})$, イオン源温度 : $230{ }^{\circ} \mathrm{C}$, 測定質量範囲 : $m / z 40 \sim 400$, 注入 量 : $1 \mu \mathrm{L}$.

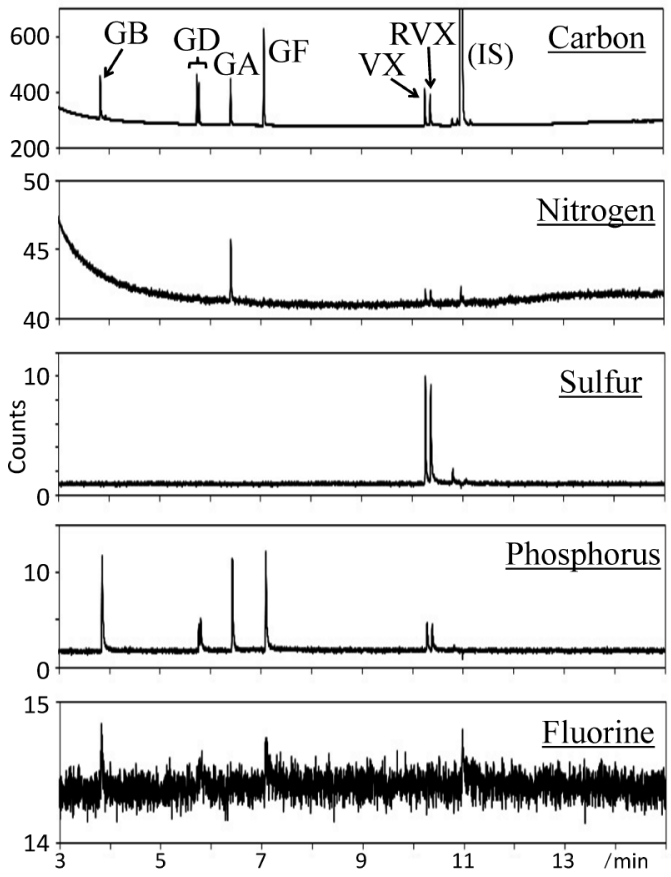

Fig. 3 Element chromatograms of nerve gases analyzed by gas chromatography-atomic emission detection at carbon (C-193 nm), nitrogen (N-174 nm), sulfur (S-181 $\mathrm{nm})$, phosphorus $(\mathrm{P}-178 \mathrm{~nm})$ and fluorine $(\mathrm{F}-690 \mathrm{~nm})$

One $\mu \mathrm{L}$ of $10-11 \mu \mathrm{g} \mathrm{mL^{-1 }}$ mixture in dichloromethane was injected, except for VX and RVX $\left(7 \mu \mathrm{g} \mathrm{mL}^{-1}\right)$. IS indicates anthracene. 
(A)


(B)


Fig. 4 Element chromatograms of chemical warfare agents

(A) Mustard gas, lewisite 1, diphenylchloroarsine, diphenylcyanoarsine and allyl isothiocyanate were analyzed at carbon $(\mathrm{C}-193 \mathrm{~nm})$, nitrogen $(\mathrm{N}-174 \mathrm{~nm})$, chlorine $(\mathrm{Cl}-479 \mathrm{~nm})$, sulfur $(\mathrm{S}-181 \mathrm{~nm})$ and arsenic (As-189 nm). (B) Nitrogen mustard 1-3, 2-chloroacetophenone, o-chlorobenzylidene malononitrile and capsaicin were analyzed by GC-AED at carbon, nitrogen and chlorine. One $\mu \mathrm{L}$ of $10-19 \mu \mathrm{g} \mathrm{mL}^{-1}$ mixture in dichloromethane solution was injected (DC and DA were singly injected). IS in (A) and (B) indicates $n$-nonadecane and anthracene, respectively.

\section{$2 \cdot 5$ 特定物質の取り扱い}

GB, GD, GA, GF, VX, RVX, HD, L1, HN1, HN2 及び HN3 は, 化学兵器禁止法において特定物質としてそ の使用などが規制されており ${ }^{20)}$ ，経済産業大臣からの使 用・製造承認を受けて，これらの特定物質に係る実験を 行った。これらの特定物質は非常に毒性が高いため, 試料 の調製はスクラバー式ドラフトチャンバー内で防護手袋等 の装着により細心の注意を払って行った。 ガスクロマトグ ラフならびに検出器のベントにチューブを取り付け, アル カリ水溶液内にバブリングさせ, 放出された特定物質を分 解させた.

\section{3 結果と考察}

3・1 GC-AED による化学兵器用剂ならびに関連化合物 の分離・検出

実際の化学兵器使用事案の鑑定においては, 現場資料か らは化学兵器用剂以外に合成中間体, 副生成物, 分解物な どの関連化合物が検出されるので, 本研究では化学剤に加 えて, 有機溶媒で抽出される関連化合物を対象とした。

各化学兵器用剂の特性ならびに GC-AEDによる分析結果 を Table 1 に, 化学兵器用剤標品の元素クロマトグラムを
Fig. 3 及び Fig. 4 に示す. 試料からの化学兵器用剤抽出の 際には, ジクロロメタンによる抽出が主となっており ${ }^{6)}$, 本研究において, 化学兵器用剂標品はジクロロメタン希釈 溶液を使用した。いずれの化学兵器用剤についても, 質量 分析のような分子構造に依存する検出とは異なり, 各化合 物に特徴的な構成元素を検出することができた，各化合物 は，熱分解性が高く不安定な L1 を除き，いずれも再現よ く検出された．各化学兵器用剂ならびに関連化合物の保持


の同定に有効となることが判明した.

化学兵器用剂の各構成元素クロマトグラムのピーク高さ から求めた検出限界, ならびに検量線における相関係数に ついて Table 2 に示す. 神経ガスである GD は, キラル不 斉炭素により 2 本のジアステレオマーのピークとして検出 され ${ }^{20)}$, 検出限界は他の神経ガスと比較して高い值となっ た.また，長波長でのフォトダイオード検出のためフッ素 の検出感度が低く，GB などのフッ素含有神経ガスにおい て，低濃度でのフッ素による元素スクリーニングは困難で あると考えられた。一方，GD以外の，窒素，リンまたは 硫黄を分子内に含有する神経ガスについては，各へテロ元 素における検出限界が数 $\mu \mathrm{g} \mathrm{mL} \mathrm{mL}^{-1}$ 以下となり検量線の直 
Table 2 Detection limits and calibration curve linearity of chemical warfare agents in gas chromatography-atomic emission detection analysis

\begin{tabular}{|c|c|c|c|c|c|c|c|}
\hline \multirow{2}{*}{\multicolumn{2}{|c|}{ Compound }} & \multicolumn{6}{|c|}{ Detection limit $/ \mu \mathrm{g} \mathrm{mL}^{-1 \text { a) }}$ (Correlation coefficient of calibration standard) } \\
\hline & & N174 & P178 & S181 & As189 & Cl479 & F690 \\
\hline \multirow[t]{5}{*}{ Nerve gases } & GB & - & $\begin{array}{c}1.0 \\
(0.995)\end{array}$ & - & - & - & $\begin{array}{c}14.2 \\
(0.986)\end{array}$ \\
\hline & GD & - & $\begin{array}{c}11.1 \\
(0.982)\end{array}$ & - & - & - & $\begin{array}{c}33.7 \\
(0.978)\end{array}$ \\
\hline & GA & $\begin{array}{c}1.5 \\
(0.997)\end{array}$ & $\begin{array}{c}0.74 \\
(0.997)\end{array}$ & - & - & - & - \\
\hline & GF & - & $\begin{array}{c}3.7 \\
(0.997)\end{array}$ & - & - & - & $\begin{array}{c}18.9 \\
(0.984)\end{array}$ \\
\hline & RVX & $\begin{array}{c}2.4 \\
(0.982)\end{array}$ & $\begin{array}{c}0.65 \\
(0.980)\end{array}$ & $\begin{array}{c}0.14 \\
(0.999)\end{array}$ & - & - & - \\
\hline \multirow[t]{5}{*}{ Blistering agents } & HD & - & - & $\begin{array}{c}0.15 \\
(0.998)\end{array}$ & - & $\begin{array}{c}1.5 \\
(0.999)\end{array}$ & - \\
\hline & L1 & - & - & - & $\begin{array}{c}8.5 \\
(0.984)\end{array}$ & $\begin{array}{c}17.4 \\
(0.949)\end{array}$ & - \\
\hline & HN1 & $\begin{array}{c}1.6 \\
(0.995)\end{array}$ & - & - & - & $\begin{array}{c}1.2 \\
(0.992)\end{array}$ & - \\
\hline & HN2 & $\begin{array}{c}1.7 \\
(0.995)\end{array}$ & - & - & - & $\begin{array}{c}1.5 \\
(0.993)\end{array}$ & - \\
\hline & HN3 & $\begin{array}{c}2.1 \\
(0.995)\end{array}$ & - & - & - & $\begin{array}{c}1.1 \\
(0.992)\end{array}$ & - \\
\hline \multirow[t]{2}{*}{ Vomiting agents } & DA & - & - & - & $\begin{array}{c}1.3 \\
(0.967)\end{array}$ & $\begin{array}{c}4.5 \\
(0.998)\end{array}$ & - \\
\hline & DC & $\begin{array}{c}3.0 \\
(1.000)\end{array}$ & - & - & $\begin{array}{c}0.47 \\
(0.955)\end{array}$ & - & - \\
\hline \multirow[t]{4}{*}{ Lachrymators } & $\mathrm{CN}$ & - & - & - & - & $\begin{array}{c}3.0 \\
(0.992)\end{array}$ & - \\
\hline & CS & $\begin{array}{c}1.1 \\
(0.995)\end{array}$ & - & - & - & $\begin{array}{c}1.2 \\
(0.991)\end{array}$ & - \\
\hline & Capsaicin & $\begin{array}{c}12.0 \\
(0.994)\end{array}$ & - & - & - & - & - \\
\hline & AITC & $\begin{array}{c}1.5 \\
(1.000)\end{array}$ & - & $\begin{array}{c}0.11 \\
(0.999)\end{array}$ & - & - & - \\
\hline
\end{tabular}

a) The detection limits are defined as analyte level that gives a signal-to-noise ratio $3: 1$.

線性も良好であり，優れた定量性を有していた。

びらん剤において，HD ならびに HN については特徴的 元素である硫黄, 窒素, 塩素を再現性よく高感度に検出す ることができ, 各化合物の検量線の直線性も良好であっ た。一方，L1 は化合物自身が不安定かつ GC 注入口におい て分解するため, 元素クロマトグラム上にも分解物と思わ れるピークが出現し (Fig. 4(A)), 特に低濃度において分 解物の割合が大きい傾向が認められた。また，L1 は注入口 やカラムに残留しやすく分解されやすいためか, 塩素にお ける検量線の直線性の相関が他の化学剤と比較しても低 く，検出感度も低い結果となった。

嘔吐（くしゃみ）剂である DA，DCは，七素における検 量線の相関が低い值となった。本分析条件において, 七素 の元素クロマトグラムにおけるピーク形状がテーリングし
ていることがその原因として考えられた．それ以外の元素 については検出感度, 検量線ともに良好な結果を示した. DC は L1 と混合した際, 一部が DAに変換される現象（シ アノ基の塩素ラジカルによる置換）が認められたが, 単独 で分析を行ったところ, 安定に検出することができた.

催涙剤のうち, カプサイシンは低揮発性であり, 高分子 量かつ窒素の元素割合が低いため検出感度が低かったが, その他の催涙剤については高感度に検出され，検量線は良 好な直線性を示した。

化学兵器用剂関連化合物の特性ならびに GC-AEDによる 分析結果を Table 3 に示す. 総じて易分解性である化学兵 器用剤は, 試料によっては分解物が検出する可能性が考え られる，また，合成品であるため，副生成物などの関連化 合物の検出により, 化合物の合成経路などの解明にも役立 
Table 3 The related compounds of chemical warfare agents analyzed and gas chromatography-atomic emission detection results

\begin{tabular}{|c|c|c|c|c|c|c|c|c|c|c|c|c|}
\hline & \multirow{2}{*}{\multicolumn{2}{|c|}{ Compound/abbreviation }} & \multirow[t]{2}{*}{$\begin{array}{l}\text { Molecular } \\
\text { formula }\end{array}$} & \multirow[t]{2}{*}{$\begin{array}{l}\text { Mol. } \\
\text { Wt. }\end{array}$} & \multirow[t]{2}{*}{$\begin{array}{c}\text { Liquid } \\
\text { or } \\
\text { Solid } \\
\text { at rt }\end{array}$} & \multirow[t]{2}{*}{$\begin{array}{l}\text { Density/ } \\
\mathrm{g} \mathrm{mL}^{-1 \text { a) }}\end{array}$} & \multicolumn{2}{|c|}{$\begin{array}{c}\text { Detection limit } \\
\text { (Correlation } \\
\text { coefficient of } \\
\text { calibration }^{\text {sibdard }}{ }^{\mathrm{c}} \text { ) }\end{array}$} & \multirow[t]{2}{*}{$\begin{array}{l}\mathrm{CV} / \mathrm{d} \\
\% \mathrm{~d}\end{array}$} & \multicolumn{3}{|c|}{ Retention index } \\
\hline & & & & & & & Element & $\mu \mathrm{g} \mathrm{mL}{ }^{-1}$ & & Exp. $^{\text {e) }}$ & Ref. $1^{f)}$ & Ref. $2^{\text {g) }}$ \\
\hline \multirow[t]{13}{*}{ Nerve gases } & $\begin{array}{l}\text { Dimethyl } \\
\text { methylphosphonate }\end{array}$ & DMMP & $\mathrm{C}_{3} \mathrm{H}_{9} \mathrm{O}_{3} \mathrm{P}$ & 124 & $\mathrm{~L}$ & 1.16 & $\mathrm{P} 178$ & $\begin{array}{c}2.9 \\
(0.998)\end{array}$ & 0.6 & 874 & 880 & 881 \\
\hline & $\begin{array}{l}\text { Diethyl } \\
\text { methylphosphonate }\end{array}$ & DEMP & $\mathrm{C}_{5} \mathrm{H}_{13} \mathrm{O}_{3} \mathrm{P}$ & 152 & $\mathrm{~L}$ & 1.05 & $\mathrm{P} 178$ & $\begin{array}{c}1.9 \\
(0.998)\end{array}$ & 0.8 & 1002 & & \\
\hline & $\begin{array}{l}\text { Diisopropyl } \\
\text { methylphosphonate }\end{array}$ & DIMP & $\mathrm{C}_{7} \mathrm{H}_{17} \mathrm{O}_{3} \mathrm{P}$ & 180 & $\mathrm{~L}$ & 0.99 & $\mathrm{P} 178$ & $\begin{array}{c}3.8 \\
(0.990)\end{array}$ & 0.8 & 1058 & 1067 & 1073 \\
\hline & $\begin{array}{l}\text { Dicyclohexyl } \\
\text { methylphosphonate }\end{array}$ & DCMP & $\mathrm{C}_{13} \mathrm{H}_{25} \mathrm{O}_{3} \mathrm{P}$ & 260 & $\mathrm{~L}$ & 1.41 & $\mathrm{P} 178$ & $\begin{array}{c}19.3 \\
(0.914)\end{array}$ & 4.4 & 1873 & & \\
\hline & Trimethyl phosphate & TMPO & $\mathrm{C}_{3} \mathrm{H}_{9} \mathrm{O}_{4} \mathrm{P}$ & 140 & $\mathrm{~L}$ & 1.22 & $\mathrm{P} 178$ & $\begin{array}{c}1.3 \\
(0.998)\end{array}$ & 2.0 & 923 & 932 & \\
\hline & Triethyl phosphate & TEPO & $\mathrm{C}_{6} \mathrm{H}_{15} \mathrm{O}_{4} \mathrm{P}$ & 182 & $\mathrm{~L}$ & 1.07 & $\mathrm{P} 178$ & $\begin{array}{c}0.85 \\
(0.998)\end{array}$ & 0.9 & 1114 & 1123 & 1137 \\
\hline & Dimethyl phosphite & DMP & $\mathrm{C}_{2} \mathrm{H}_{7} \mathrm{O}_{3} \mathrm{P}$ & 110 & $\mathrm{~L}$ & 1.20 & $\mathrm{P} 178$ & $\begin{array}{c}4.3 \\
(0.985)\end{array}$ & 2.0 & 806 & & \\
\hline & Diethyl phosphite & DEP & $\mathrm{C}_{4} \mathrm{H}_{11} \mathrm{O}_{3} \mathrm{P}$ & 138 & $\mathrm{~L}$ & 1.07 & $\mathrm{P} 178$ & $\begin{array}{c}1.0 \\
(0.996)\end{array}$ & 2.5 & 950 & & \\
\hline & Diisopropyl phosphite & DIP & $\mathrm{C}_{6} \mathrm{H}_{15} \mathrm{O}_{3} \mathrm{P}$ & 166 & $\mathrm{~L}$ & 1.00 & $\mathrm{P} 178$ & $\begin{array}{c}1.1 \\
(0.967)\end{array}$ & 2.8 & 1024 & & \\
\hline & Trimethyl phosphite & TMP & $\mathrm{C}_{3} \mathrm{H}_{9} \mathrm{O}_{3} \mathrm{P}$ & 124 & $\mathrm{~L}$ & 1.05 & $\mathrm{P} 178$ & $\begin{array}{c}0.62 \\
(0.992)\end{array}$ & 2.3 & 733 & & \\
\hline & Triethyl phosphite & TEP & $\mathrm{C}_{6} \mathrm{H}_{15} \mathrm{O}_{3} \mathrm{P}$ & 166 & $\mathrm{~L}$ & 0.96 & $\mathrm{P} 178$ & $\begin{array}{c}0.87 \\
(0.997)\end{array}$ & 1.4 & 922 & & \\
\hline & Triisopyl phosphite & TIP & $\mathrm{C}_{9} \mathrm{H}_{21} \mathrm{O}_{3} \mathrm{P}$ & 208 & $\mathrm{~L}$ & 0.91 & $\mathrm{P} 178$ & $\begin{array}{c}3.0 \\
(0.997)\end{array}$ & 1.0 & 1013 & & \\
\hline & Pinacolyl alcohol & & $\mathrm{C}_{6} \mathrm{H}_{14} \mathrm{O}$ & 102 & $\mathrm{~L}$ & 0.82 & - h) $^{\text {h }}$ & - & 1.1 & 740 & & \\
\hline \multirow[t]{2}{*}{$\begin{array}{l}\text { Blistering } \\
\text { agents }\end{array}$} & 1,4-Thioxane & & $\mathrm{C}_{4} \mathrm{H}_{8} \mathrm{OS}$ & 104 & $\mathrm{~L}$ & 1.12 & S181 & $\begin{array}{c}0.059 \\
(0.999)\end{array}$ & 0.2 & 892 & & 880 \\
\hline & 1,4-Dithiane & & $\mathrm{C}_{4} \mathrm{H}_{8} \mathrm{~S}_{2}$ & 120 & $\mathrm{~S}$ & - & S181 & $\begin{array}{c}0.036 \\
(0.998)\end{array}$ & 0.2 & 1084 & & 1060 \\
\hline \multirow[t]{2}{*}{ Lachrymators } & Acetophenone & & $\mathrm{C}_{8} \mathrm{H}_{8} \mathrm{O}$ & 120 & $\mathrm{~L}$ & 1.03 & - h) $^{\mathrm{h}}$ & - & 3.0 & 1074 & & \\
\hline & $o$-Chlorobenzaldehyde & & $\mathrm{C}_{7} \mathrm{H}_{5} \mathrm{ClO}$ & 141 & $\mathrm{~L}$ & 1.25 & C1479 & $\begin{array}{c}2.9 \\
(1.000)\end{array}$ & 3.0 & 1131 & & \\
\hline
\end{tabular}

a) At $20^{\circ} \mathrm{C}$. b) The detection limits are defined as analyte level that gives a signal-to-noise ratio $3: 1 . \quad$ c) Calibration curve linearity. d) Coefficient of variation in within-day $\left(16-28 \mu \mathrm{g} \mathrm{mL}{ }^{-1}\right)$ at carbon $(193 \mathrm{~nm})(n=3)$. e) Retention index for each compound is calculated using its retention time at carbon (193 nm). f) Reference: 21). g) Reference: 22) and 23). h) These compounds contain no hetero elements.

てることができる，関連化合物には，単一のへテロ元素を 含有するものが多数存在しており，これらのへテロ元素を もとにしたスクリーニングが可能であると推察される. Table 3 に示すように, ヘテロ元素組成割合の低い DCMP と, ヘテロ元素を有していないピナコリルアルコールとア セトフェノンを除き，いずれの関連化合物についても 1 種 類の特徴的へテロ元素を高感度かつ安定に再現よく検出す ることができた．また，検量線の直線性も非常に良好で あった。

\section{$3 \cdot 2$ 各元素面積比を用いた化学兵器用剤の同定への応用}

AED においては, 既知化合物の炭素と各元素のピーク面 積比を基に, 未知化合物の炭素と各元素の数比を求めて組 成式の推定を行うことが可能である ${ }^{24)}$. すなわち, 同一化 合物であれば，濃度が異なる場合においても各元素のピー ク面積比は理論上一定となることに基づいている。 そこ で, 複数の特徴的へテロ元素が存在する化学兵器用剤につ いて, これらの 2〜200 $\mu \mathrm{g} \mathrm{mL}^{-1}$ (または $\mathrm{nL} \mathrm{mL}^{-1}$ ) にお けるへテロ元素のピーク面積比を求め, 化学兵器用剤の同 定に応用できるか考察した，その結果を Table 4 に示す.

神経ガスの場合，いずれに押いても $\mathrm{CV}$ 值が $10 \%$ 以上 
Table 4 Peak area ratio of hetero elements of chemical warfare agents analyzed by gas chromatography-atomic emission detection

\begin{tabular}{|c|c|c|c|c|c|c|c|}
\hline Compound & $\mathrm{A} / \mathrm{B}^{\mathrm{a})}$ & Area ratio ${ }^{\text {b) }}$ & $\mathrm{CV} / \%$ & Compound & $\mathrm{A} / \mathrm{B}$ & Area ratio & $\mathrm{CV} / \%$ \\
\hline GB & P178/F690 & $15.5 \pm 2.5$ & 16.4 & HD & S181/Cl479 & $8.3 \pm 0.54$ & 6.5 \\
\hline GD & P178/F690 & $12.0 \pm 1.6$ & 13.6 & L1 & As189/Cl479 & $21.8 \pm 6.2$ & 28.6 \\
\hline GA & $\mathrm{P} 178 / \mathrm{N} 174$ & $2.3 \pm 0.7$ & 29.3 & HN1 & $\mathrm{Cl} 479 / \mathrm{N} 174$ & $1.3 \pm 0.038$ & 2.8 \\
\hline \multirow[t]{2}{*}{ GF } & P178/F690 & $12.7 \pm 1.9$ & 14.8 & HN2 & $\mathrm{Cl} 479 / \mathrm{N} 174$ & $1.3 \pm 0.044$ & 3.3 \\
\hline & $\mathrm{S} 181 / \mathrm{N} 174$ & $10.1 \pm 3.3$ & 32.6 & HN3 & $\mathrm{Cl} 479 / \mathrm{N} 174$ & $2.0 \pm 0.075$ & 3.8 \\
\hline \multirow[t]{3}{*}{ VX } & $\mathrm{S} 181 / \mathrm{P} 178$ & $1.9 \pm 0.3$ & 16.1 & DA & As189/Cl479 & $49.7 \pm 9.0$ & 18.1 \\
\hline & $\mathrm{P} 178 / \mathrm{N} 174$ & $5.6 \pm 2.6$ & 46.7 & DC & As189/N174 & $41.2 \pm 6.8$ & 16.4 \\
\hline & S181/N174 & $10.4 \pm 2.3$ & 22.0 & CS & $\mathrm{N} 174 / \mathrm{Cl} 479$ & $2.8 \pm 0.27$ & 9.8 \\
\hline \multirow[t]{2}{*}{ RVX } & S181/P178 & $2.5 \pm 0.6$ & 24.8 & AITC & S181/N174 & $13.5 \pm 0.62$ & 4.6 \\
\hline & $\mathrm{P} 178 / \mathrm{N} 174$ & $4.6 \pm 2.1$ & 46.2 & & & & \\
\hline
\end{tabular}

a) $\mathrm{A}$ and $\mathrm{B}$ are defined as the larger and smaller peak area of the hetero elements, respectively. b) Peak area ratios in 2, 10, $20,50,100$ and $200 \mu \mathrm{g} \mathrm{mL}^{-1}$ or $\mathrm{nL} \mathrm{mL}^{-1}$ of chemical warfare agents are averaged.

(A)

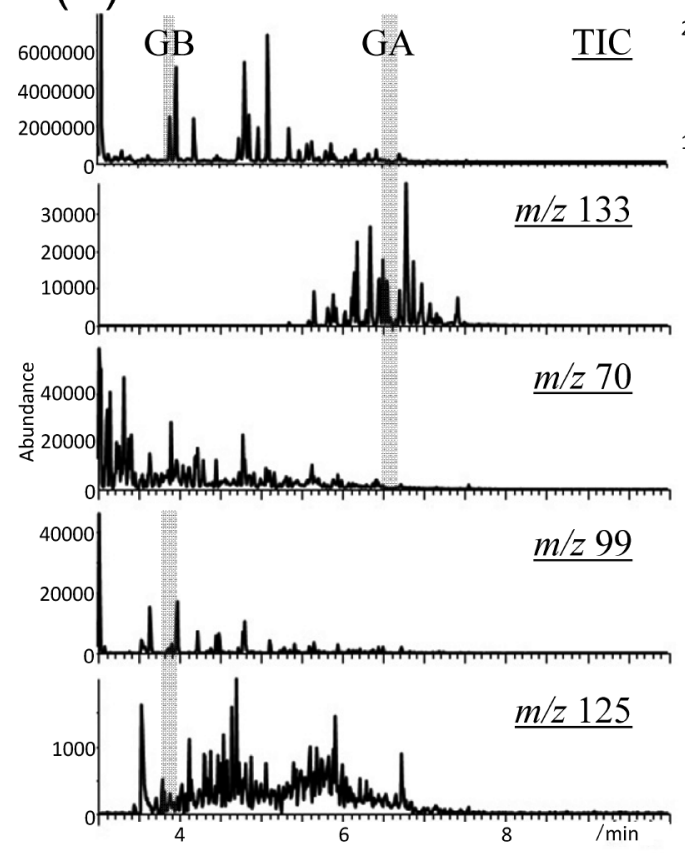

(B)
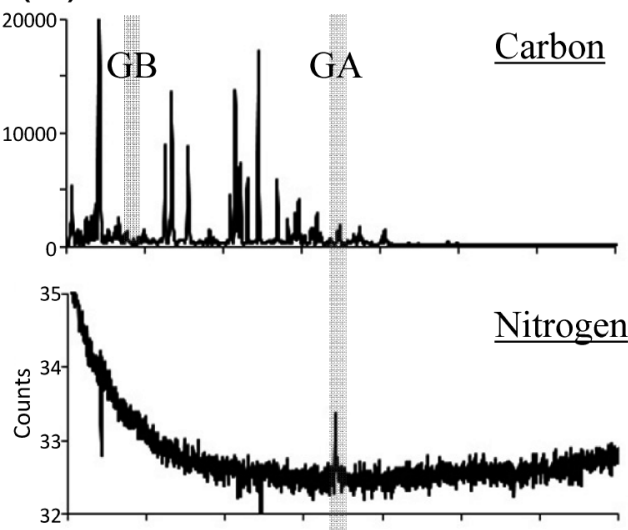

$\underline{\text { Phosphorus }}$

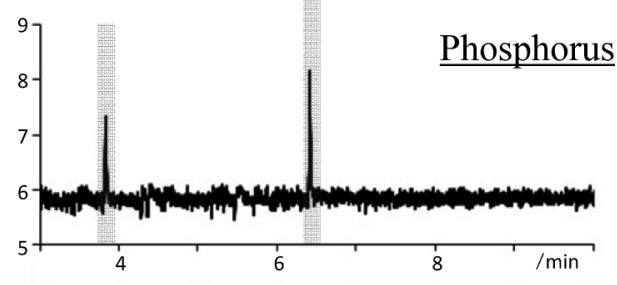

Fig. 5 (A) Total ion chromatogram and extracted ion chromatograms in gas chromatography/mass spectrometry, and (B) element chromatograms in gas chromatography-atomic emission detection (C-193 $\mathrm{nm}, \mathrm{N}-174 \mathrm{~nm}$ and P-178 nm) of the mixture of ENEOS regular gasoline $\left(100 \times\right.$ diluted) and $2 \mu \mathrm{g} \mathrm{mL}^{-1}$ sarin and tabun in $n$-hexane.

と, 濃度による面積比のバラツキが大きく, かつ GB, GD, GF はフッ素の検出感度が低いため, $20 \mu \mathrm{g} \mathrm{mL}^{-1}$ 以上の濃 度範囲に限定された，GA，VX，RVXについては，高感度 である硫黄やリンを用いた面積比もばらついており，神経 ガス自身の分析時における熱分解などの考慮が必要である と考えられた。ただし，これらの特徵的構成元素の有無と 各化合物の保持指標とを組み合わせることで, 神経ガスの スクリーニングは可能であると推察された。

神経ガス以外の化学兵器用剤について, 七素化合物であ るL1，DA，DCを除いていずれも CV 值が 10 \% 以下とな
り，広い濃度範囲において非常に再現性よいピーク面積比 が得られた.これらの化合物は GC 測定において安定であ ると考えられることから, 保持指標と特徽的元素のピーク 面積比から化合物の同定が可能であると判断した，安定性 の低い L1 及び DA，DCについても，構成元素の有無を把 握することができるため，保持指標と組み合わせることで 各化合物のスクリーニングに有効であることが判明した.

化学兵器用剤関連化合物についても, 単一のへテロ元素 の有無と保持指標とから，関連化合物のスクリーニングに 応用できると判断された. 
$3 \cdot 3$ 夾雑物含有試料中の化学兵器用剤スクリーニング への適用

様々な夾雑物含有試料から化学兵器用剤を検出するため には, 液液抽出などの夾雑物の除去などによる目的化合物 精製が前処理として通常行われる. しかしながら, 高揮発 性である GB などの化学兵器用剤は, 抽出後の溶液濃縮時 に揮散してしまう。また，前処理法によっては夾雑物が除 去されない場合もあり, 通常の GC/MS 法において目的化 合物が検出されない場合も想定される。 そこで，夾雑物と して揮発性炭化水素を多く含有するガソリンを模擬試料と して使用し，化学兵器用郕のスクリーニングへの適用を試 みた。

GC/MS ならびに GC-AED による GA ならびに GB 含有 希釈ガソリン溶液の分析結果を Fig. 5 に示す. GC/MS 測 定の場合（Fig. 5 (A)), 大過㮃のガソリン成分により GA 及び $\mathrm{GB}$ の主要な検出イオンである $m / z 133,70$ 及び 99 , 125 においてピークを検出することができなかった，一方， 同じサンプルを GC-AED で測定した場合（Fig. 5 (B)）, フッ素については検出限界以下のため検出できなかったも のの, 標準試料と同じ GA, GB の保持時間にリン及び窒素 を検出することができ, これらの化学兵器用剤の存在を推 定することができた．

$$
4 \text { 結 言 }
$$

GC/MS 測定において目的化合物の検出を妨害する複雑 なマトリクスを有する試料について，GC-AED 法はその影 響を受けることなく化学兵器用剤ならびに関連化合物のス クリーニングあるいは同定が可能であり，GC/MS 法を補 完する分析法であると結論できる.

\section{文献}

1) 警察庁 : 警察白書, 1994-1995.

2) Y. Seto, N. Tsunoda, M. Kataoka, K. Tsuge, T. Nagano: “Toxicological analysis of victims' blood and crime scene evidence samples in sarin gas attack caused by the AUM SHINRIKYO cult", Edited by A. T. Tu, W. Gaffield, p. 318 (1999), (American Chemical Society, Washington, DC).
3) T. V. Inglesby, T. O’Toole, D. A. Henderson, J. G. Bartlett, M. S. Ascher, E. Eitzen, A. M. Friedlander, J. Genberding, J. Hauer, J. Hughes, J. McDade, M. T. Osterholm, G. Parker, T. M. Perl, P. K. Russell, K. Tohat: J. Am. Med. Assoc., 287, 2236 (2002).

4) 瀬戸康雄 : 薬学雑誌, 126, 1279 (2006).

5) 瀬戸康雄, 金森美江子, 柘浩一郎：J. Mass Spectrom. Soc.Jpn., 56, 91 (2008).

6) M. Raurio (Ed.) : "Recommended Operating Procedures for Sampling and Analysis in the Verification of Chemical Disarmament", (1994), (The Ministry for Foreign Affairs of Finland, Helsinki).

7) 瀬戸康雄：分析化学 (Bunseki Kagaku), 56, 981 (2007).

8) M. Kanamori-Kataoka, Y. Seto : J. Health Sci., 54, 513 (2008).

9) R. Haas, T. C. Schmidt, K. S. E. von Löw : Fresenius J. Anal. Chem., 361, 313 (1998).

10) S. Gura, N. Tzanani, M. Hershkovitz, B. S. Dagan : Arch. Environ. Contam. Toxicol., 51, 1 (2006).

11) J.-P. Le Harle, B. Bellier : J. Chromatogr. A, 1087, 124 (2005).

12) J. T. Andersson : Anal. Bioanal. Chem., 373, 344 (2002).

13) L. L. P. van Stee, J. Beens, R. J. J. Vreuls, U. A. Th. Brinkman : J. Chromatogr. A, 1019, 89 (2003).

14) K. Schoene, H.-J. Bruckert, H. Jürling, J. Steinhanses : J. Chromatogr. A, 719, 401 (1996).

15) M. D. Brickhouse, W. R. Creasy, B. R. Williams, K. M. Morrissey, R. J. O'Connor, H. D. Durst: J. Chromatogr. A, 883, 185 (2000).

16) M. Mazurek, Z. Witkiewicz, S. Popiel, M. Śliwakowski : J. Chromatogr. A, 919, 133 (2001).

17) S. Hanaoka, K. Nomura, S. Kudo : J. Chromatogr. A, 1085, 213 (2005).

18) T. J. Reddy, U. V. R. V. Saradhi, S. Prabhakar, M. Vairamani : J. Chromatogr. A, 1038, 225 (2004).

19) A. C. Moffat, K. W. Smalldon, C. Brown : J. Chromatogr., 90, 1 (1974).

20）黑田紀幸：衛生化学, 43, 155 (1997)。

21) 瀬戸康雄, 井浦一光, 金森美江子: 法科学技術, 10, 49 (2005).

22) P. A. D’Agostino, L. R. Provost : J. Chromatogr., 331, 47 (1985).

23) P. A. D'Agostino, L. R. Provost : J. Chromatogr., 436, 399 (1988).

24) J. T. Anderson : Anal. Bioanal. Chem., 373, 344 (2002). 


\title{
Analysis of Chemical Warfare Agents and Their Related Compounds Using Gas Chromatograph with Atomic Emission Detector
}

\author{
Mieko Kanamori-Kataoka $^{\circledR 1}$, Masumi Tachikawa ${ }^{1,2}$, Ryoji Sekioka ${ }^{1,3}$, Hiroshi Sekiguchi ${ }^{1,3}$, \\ Hisashi MARuko ${ }^{1,3}$, Takafumi SATO ${ }^{1,3}$ and Yasuo SETO ${ }^{1}$ \\ ${ }^{\circledR}$ E-mail : kataoka@nrips.go.jp \\ ${ }^{1}$ National Research Institute of Police Science, 6-3-1, Kashiwanoha, Kashiwa-shi, Chiba 277-0882 \\ ${ }^{2}$ Hitec, Inc, Hosokawa Building, 1-15-1, Benten, Chuo-Ku, Chiba-shi, Chiba 260-0045 \\ ${ }^{3}$ Tokyo Metropolitan Police Department, 2-1-1, Kasumigaseki, Chiyoda-ku, Tokyo 100-8929
}

(Received July 20, 2012; Accepted August 24, 2012)

Gas chromatographic analysis with atomic emission detection (GC-AED) was performed for 17 chemical warfare agents (CWAs) and their 17 related compounds. Specific hetero elements in all CWAs and their related compounds were clearly detected, and their detection limits, linearity of their calibration curve, and within-day variability were evaluated. Some CWAs could be identified with respect to their peak area ratios of their hetero elements and their retention indices. GC-AED can be a powerful tool for screening CWAs in a complex matrix.

Keywords: chemical warfare agents; gas chromatography; atomic emission detection. 